\title{
SOOMEUGRILUSEST EESTI RAHVUSPILDIS - KAS JAGATUD EMOTSIOON VÕI HÄGUNE KÜSITAVUS?
}

\author{
MADIS ARUKASK
}

$\mathrm{R}$ ahvusluse olemuse debattides käib vaidlus selle üle, kas see on midagi loomulikult eksisteerivat või pelk konstruktsioon, vaieldav ja suhteline nähtus. Soovimata sellesse arutellu eriliselt süüvida, peab tõdema, et rahvusluse komponendid ja „elavad allikad” varieeruvad ja on ajas teinekord vägagi muutlikud.

Nii tekkis rahvuslus Eestis ja mujalgi Ida-Euroopas XIX sajandil, toetudes folkloorile, traditsioonilisele eluviisile ja keelele. Need olid rahvusteks kujunevate, seni otsekui näota rahvaste eripära ainsad tõsiselt võetavad kinnitused, nende eluõiguse tõestus. Rahvakultuurist vormiti eestlaste psühholoogiline ajalugu, mis XIX sajandil suurepäraselt oma ülesannet täitis. Hiljem, XX sajandist alates, hakkas rahvakultuur muunduma allikast dekoratsiooniks. Pidades silmas tähelepanu ja ressursse, mis rahvakultuurile eraldatakse (näiteks Eesti Kultuurkapitali süsteemis), on tänapäeval tegemist juba selgelt ripatsi, kõrvalnähtusega. Avastatud ja avatud „pärisajaloo” allikad (Henriku jt kroonikad) asusid XIX sajandil teenima vastanduse narratiivi - samuti olulist identiteedi komponenti. Sakslastele oponeerimist rahvuse loos on uutel aegadel asutud ümber vaatama. Iseolemise sisu määratlemisega ollakse justkui hädas ja suurimaks abivahendiks eestluse identifitseerimisel paistab XX sajandi lõpust alates olevat idavastandus ja oma läände sobivuse tõestamine.

Selle kirjutise teemaks on soomeugriluse uurimine eesti rahvuse loos ja rahvusluses. Kindlasti pole tegemist süvaanalüüsiga, vaid pigem üksjagu isiklike mõtetega ajaloost ja tänasest päevast. Küsimusteks on: milline on soomeugri komponendi kaal ja tähtsus rahvuse ajaloo eri etappidel XIX sajandist meie päevini? Milline on teaduslikkuse ning emotsionaalse müüdiloome osa selles? Kuidas on suhtumine ja huvi soome-ugri rahvaste vastu jagunenud ida-lääne teljel? Kas soome-ugri komponent eesti identiteedis on „kuum” või „külm”?

\section{Müüdi lätetel}

Essees „Soomeugri müüt” on Hasso Krull iseloomustanud soomeugrilust laiemas kultuurilises mõttes nii: „[---] soomeugrilusest saab sünteetiline konstruktsioon, mis lööb põhimõtteliselt lahku soomeugrilusest kui lingvistilisel analüüsil põhinevast rekonstruktsioonist." (Krull 2014 [2010]: 239) Krull küsib, milline on soomeugriluse tegelik funktsioon Eesti kultuuris, ning tõdeb, et soomeugriluse seos eesti rahvuslusega ei ole sugugi lihtne ega ühemõtteline 
(Krull 2014 [2010]: 240, 242). Sellega tuleb nõustuda. Et juba rahvuslus ise kipub olema mütoloogilist mõõtu nähtus (ükskõik siis mis mõttes), ongi küsimus selles, kuidas selle sisse on mahtunud ja mahub ehk veelgi meie keeleliskultuuriline soome-ugri päritolukomponent ning kuidas see peegeldub (või ei peegeldu) argi- ja teaduslikus mõtlemises, poliitikas, rahvusteadustes.

Keeleteaduslik fennougristika ja hõimlaste etnograafiline uurimine, samuti muud põgusamat sorti teaduslikud kokkupuuted hõimurahvastega on eesti rahvuslusest vanemad. Kristian Jaak Peterson tundis soome keelesugulust, kuid tema tekstides ei leidu viiteid muudele hõimurahvastele peale liivlaste ja kuralaste. Kõiki neid läänemeresoomlasi pidas Peterson algupärasteks germaanlasteks (vt Peterson 2001). Siiski võiks tema rootsi keelest saksa keelde tehtud Christfrid Gananderi „Mythologia Fennica” mugandatud tõlget pidada omamoodi hõimuliikumise eelakordiks. Nn eesti pseudomütoloogia, mis aga XIX sajandil muutus ju ajutiselt tegelikuks rahvususundiks, pärines soome (tegelikult muidugi karjala) rahvausu allikatest. Nii oli Peterson esimesi moodsaid soomeugriliku meelesilla ehitajaid. Eesti rahvusluse diskursusse pole (veel?) mõtet lugeda XIX sajandi (balti)saksa päritolu loodusteadlaste (Friedrich Wilhelm von Parroti, Karl Ernst von Baeri, Alexander von Schrenki, Alexander Theodor von Middendorffi, Ernst Reinhold von Hofmanni) maininguid Siberi rahvaste kohta, mida nad oma reisikirjeldustes tegid.

Fennougristika rajajad, sealhulgas tegelikke välitöid teinud Anders Johan Sjögren, Antal Reguly, Ferdinand Johann Wiedemann, Matias Aleksanteri Castrén jt asusid soome-ugri keelesugulust teaduslikult retušeerima. Venemaa Teaduste Akadeemia - mille idauuringute kaudu täideti nii teaduslikke kui ka keisririigi geopoliitilisi eesmärke - oli fennougristika ideede levikukeskkonnaks ka Eestimaa teadlastele. Eesti esimeseks fennougristiks võib pidada Ferdinand Johann Wiedemanni, Venemaa TA akadeemikut, kellel eesti keele uurimise kõrval jagus huvi komi, mari, udmurdi, ersa, liivi, kreevini jt keelte vastu. Wiedemann polnud üksnes kabinetiteadlane, vaid töötas võimalusel alati keelekeskkonnas. Tallinnas ja Peterburis töötades kasutas ta keelejuhtidena armeelaevastiku soomeugrilastest madruseid.

Soome-ugri hõimuteema kõlas Eestis XIX sajandil laiemalt vastu ikkagi peamiselt enese suhestamises soomlaste ja Soomega. Soome-imetluse ja Soomega võrdluse esimesi lähtekohti oli eepos „Kalevala” ja soomlaste rahvuslik emantsipeerumine. Soome eeskuju ja iha samasuguse põlve järele kajastus ajalugude võrdluses. Just ajaloos, Rootsi kuningakrooni alluvuses ja Vene keisri antud autonoomias XIX sajandil kajastus soomlaste õnnelikum saatus. Selle idealiseeriva vaate on hiljaaegu kahtluse alla seadnud ajaloolane Andres Adamson (2017), kuid see ei muuda kuigivõrd juba käibivat mentaliteediloolist meemi soome kultuuriloo ülevusest, „Soome sillast” ning sellest välja kasvanud suure ja väiksema venna dihhotoomiast. Suur tükk eestlaste soomeugrilisest identiteedikomponendist rajanebki sellel Soome-seosel, küllaltki läänelikul kultuurisuhtel, mis oli oluline nii ärkamisajal kui ka sõjaeelse vabariigi päevil.

Eesti ning Soome (sekka ka Ungari) seostamise kõrvale hakkas XIX sajandi lõpust mahtuma teavet ka idapoolsetest hõimurahvastest. Esimeseks eesti soost fennougristiks peetakse Mihkel Vesket, kes sai sellekohase akadeemilise hariduse 1860. ja 1870. aastatel Leipzigis ning seejärel, pärast mõneaastast 
Eesti-perioodi, töötas Kaasani ülikoolis, kus ta elukaar haiguse tõttu enneaegselt lõppes. Veske tegi välitöid maride ja mordvalaste hulgas. Seega oli ta suhe hõimurahvastega enamat kabinetiteadusest, teoreetilisest konstruktsioonist või fantaasiast. Rõhutan vahetu kokkupuute olulisust, sest paraku on meie suhe enamiku hõimurahvastega ikkagi kellegi vahendatud, kuuldul põhinev. Kunagi pole liiga palju olnud neid eestlasi, kes idapoolsete hõimurahvaste esindajatega tegelikult kokku puutunud oleks.

Veskega sarnaselt oli idapoolsete läänemeresoome hõimurahvastega vahetu kokkupuude ka Matthias Johann Eisenil. Tema teadetes kajab vastu toon, mis on tuttav juba varasematest, XIX sajandi eri rahvusest fennougristide välitöömärkmetest. See kõneleb hääbumisest, mahajäämusest, kultuurilistest erinevustest, vene mõjudest, teistsugususest, ka lootusetusest. Kui kehvasti ei ole eestlastel ajaloos ka läinud, võrreldes kümnete teiste hõimlastega on meil lood ju ikkagi paremad. Süüdlaseks selles pärsituses on Vene ajalooline riiklus, ka vene kultuurimõjud. Eisen kirjutab näiteks: „Meie sugulased sulavad alatasa, sulavad haridust saades, sulavad ilma hariduseta. Ainult kaks rahvast - soomlased ja magyarid - on jõudnud oma iseloomu alal hoida, ilma et haridus sellele raskeid haavu oleks löönud. Mida enam rahvas end killustab, seda suuremate sammudega kõnnivad need killud sulamise poole, seda rutemini kaovad üksikud killud.” (Eisen 2008 [1922]: 222)

Loomulikult on selles vaates tõtt. Teise iseloomuliku häälena on siin tunda otsekui patroneerivat tooni, mis on saanud edaspidigi üha valdavamaks. Pehmemas või räigemas vormis kajab sellest vastu eestlaste endi „suure venna” sündroom väiksemate hõimlaste suhtes. Kui palju põhineb see vendlus aga tegelikul hõimlaste tundmisel või siiral emotsioonil? See võiks olla eesti identiteedi testküsimus soomeugriluse vallas. Võttes sellise, sageli stereotüüpse suhtumise kaudu hõimurahvastelt ära nende agentsuse, õiguse end tunda sellistena, nagu nad ajalooliselt on kujunenud, projitseeriks ja kompenseeriks eesti rahvusmõte justkui iseenda komplekse.

Pilt sarnaneb XIX sajandi teisel poolel Soome intellektuaalide seas hoogu saanud karelianismiga - huviga oma kultuurilise algupära vastu, mis nägi samas Karjala rahvaste õigeusklikes rahvakultuurides irdumist „puhtast” soome kultuurist, omamoodi rikutust. Ennemini oli „puhas” läänepoolne, asjaosalistele tuttavam kodune miljöö. Ka meie oma argimõtlemises ei kipu märkama saksa laenude suurt hulka eesti kultuuris ja keeles, sest mõistetavatel põhjustel ei ole eestlus mingil muul moel meile tuttav ega tunnetatav. Ta saaks muudmoodi tuttav olla vaid mingis muus suhteperspektiivis - kas või hõimurahvaste tegeliku tundmise kaudu. Võin kinnitada, et eestluse tajumine näiteks vepsa pärimuskultuuri ja keele kaudu on iselaadne, võimas kogemus.

Taust, millele meie tutvus idapoolsete hõimlastega on juba algusest peale asetunud, on poliitiline või politiseeritud. Kui palju meie rahvuslik narratiiv vähemasti XX sajandi algupooleni, Vene revolutsiooni ja Vabadussõjani saksa ajaloolist anastavat osa ka ei põhjanud, sama vajalik on sealt edasi olnud vastandumine idale, mis väljendub just vene kultuuris, Vene riikluses, veneluses selle mis tahes vormis. Selles suhtes on objektiivset reaalsust ja ajaloolist paratamatust. Sellesse patta on stereotüüpselt, otsimata ja otsitult sageli läinud aga ka muu venemaine, sh meie hõimurahvad. 
Idasuhte dominanti on seoses soomeugriluse ja meie rahvusega suutnud nihutada vaid mõned mõtlejad - Oskar Loorits, Uku Masing, Jaan Kaplinski, kui põhilisi nimetada. Nende sageli müüdi mõõtu nägemused ja narratiivid on mõjutanud ja mõjutavad siiani neid, kes meie sügavaimate kultuuriliste tagamaade üle mõtlema vaevuvad. Loorits pidas eestlasi idarahvaks ning paigutas ida-lääne kultuuripiiri (erinevalt Eerik Laidist, Gustav Rängast, Lennart Merist jpt) Läänemerele, mitte Narva jõele. Ta maalis pildi soomeugrilisest taigavööndi metsaminevikust, selle iselaadsest, ka pärssivast mõjust meie soome-ugri psüühele. Tõsi, ta polnud selles osas ei esimene ega originaalne (vrd nt Prants 2008: 15). Siiski tähistasid just lääs ja germaani kultuurikontaktid Looritsa jaoks vaimset ja kultuurilist allakäiku.

Masingu boreaalne narratiiv on ehk veelgi võimsam näide meie kuuluvusest hoopis teise meelkonda, kui seda on lääne „igermaanlik” mentaliteet ja maailmavaade. Viimase suhtes on Masing pehmelt öeldes irooniline. Masingult suuri mõjutusi saanud, kuid mitte neisse kinni jäänud Kaplinski idahaare on samuti lai, mahutades endasse soome-ugri rahvad, nende keele- ja meelemaailma. Kaplinskigi küsib soomeugriluse tähenduse kohta: „On's kauge ääremaa rahvaste kultuuris midagi, mida meil tasuks meenutada, midagi, millest oleks õppida, või on tegu vaid mahajäänud pooleurooplastega, kellega meid ei seo midagi peale mõne sõnatüve ja omaaegsete uurijate - Castréni, Donneri, Harva, Lehtisalo ja teiste - entusiasmi?" (Kaplinski 2004b [1998]: 192) Kaplinski vastus on vaikimisi hõimurahvaste poole hoidev ja viib meid nendega ühise maailmapildi lätetele, mis on leitavad keeles ja mõtlemises.

XIX sajandi teine pool ja XX sajandi algus oli eesti kultuuri jaoks itta pöördumise aeg. Väljarändamise tõttu laienes eesti diasporaa ulatuslikult, paraku jääb oletuslikuks küsimus, kas see oleks pikemas perspektiivis toonud kaasa kultuurilisi lähenemisi ja otsekontakte hõimurahvastega. Arvestades Nõukogude Venemaal juba 1920-ndate lõpust alanud repressioone rahvuse pinnal, pole optimismiks ülearu põhjust. Veel 1930-ndate keskpaigani toiminud Nõukogude Liidu vähem arenenud põlisrahvusi toetav poliitika (vn коренизация) vahetas välja venestussurve, mis ei ole säästnud ühtegi väikerahvast ning vaatab vastu ka Venemaa praeguste rahvusarhitektide (Valeri Tiškoviga eesotsas) suunaseadmistest.

Eesti Vabariigi sünd mõjus eestlastele tsentripetaalselt. Kodumaale tagasipöördumist soodustasid loomulikult sündmused ja suhtumised punasel Venemaal. Mõneks ajaks jäi uks ida poole üsna suletuks nii tavainimestele kui ka teadustööle. XX sajandi jooksul ennast leidnud ja samas end otsekui muust isoleerinud eesti rahvusmõttele peaks siiski meelde tuletama, kuivõrd kosmopoliitne ja asjatundlik Venemaa inimeste ja olude suhtes oli suur osa meie rahvuslikust eliidist veel saja aasta eest. Venemaal saadi haridust, teeniti armee- ja tsiviilteenistuses, tehti karjääri ja osaleti riiklikes arendustegevustes. Venemaa tegelik stereotüüpideta tundmine oli loomuomane eesti rahvusintelligentsile, kuid jäi kättesaamatuks iseseisvas vabariigis üles kasvanud põlvkonnale või omandas nende jaoks teise värvingu.

Eesti rahvusteadustele eestikeelses Eesti Vabariigis ja ülikoolis oli uks soome-ugri maailma ahtake. Tegelikud kontaktid hõimurahvastega pidid piirduma Eesti Ingeri, Läti Liivi ranna, muidugi ka Soome ja Ungariga. Eesti Vabariigi edusammud hõimutöös Narva jõe tagustel aladel olid vastuolulised 
ning tõid kaasa kriitikat ka Soome poolt seoses isurite ja soomlaste vägivaldse eestistamisega. Hoopis paremini edenes Eesti, Soome ja Ungari koostöö Liivi rannas, liivlaste kultuuri- ja hariduselu toetamisel. Ka liivi keele ja rahvakultuuri teaduslik uurimine sai Läti Vabariigi kohatiste valulike reaktsioonide kiuste hoo sisse. Kaugem idasuund jäi suletuks. 1925. aastal käis Julius Mark küll ekspeditsioonil maride ja mordvalaste juures, 1921. ja 1922. aastal andis Tartu Ülikoolis (TÜ) loenguid komi teadlane Kallistrat Žakov ning 1926. aastal esines Tartus Akadeemilises Hõimuklubis (see loodi aastal 1923) komi Vassili Lõtkin (Prozes 2012: 105). Idapoolsete hõimlastega otsesidemete puudumisel tuli hõimuenergiat ammutada pigem suguluse müüdist kui reaalsetest teadus- ja kultuurikontaktidest.

Samal ajal paistab sõjaeelse Eesti Vabariigi aeg just ühiskondlikus plaanis silma soomeugrilise riikliku arendustöö poolest. Võrreldes tänasega võib öelda, et nii tegelik soomeugrilus kui ka soome-ugri teema mütoloogilisus puudutas ühiskonda ja selle eliiti märkimisväärselt. Fenno-Ugria Asutise loomisega 1927. aastal pandi alus riiklikult korraldatud ja toetatud, samas sisult ühiskondlikule hõimutööle. Piisab, kui heita pilk Fenno-Ugria toonasele liikmeskonnale, mis ei koondanud (erinevalt organisatsiooni tänasest seisust) üksnes kultuuri- ja haridustegevusega seotud liikmesorganisatsioone ja isikuid. Asutise nõukogu juhatajaks valiti riigivanem Konstantin Päts, üheks abiks sai Peeter Põld. Fenno-Ugriasse kuulus lõpuks ligi 40 organisatsiooni, sealhulgas mitte üksnes kultuuriklubid, vaid näiteks ka Eesti Põllumeeste Keskselts, Eesti Õpetajate Liit, Kaubandus-Tööstuskoda, Eesti Arstide Liit, Kaitseliit, Eesti Apteekrite Selts jt (Prozes 2012: 109).

Sõjaeelse olukorraga võrreldes väljendub riiklikult prominentsete isikute huvi teema vastu tänapäeval ehk parlamendi soome-ugri toetusrühma olemasolus. Selliste rühmade tegelik efekt on praegu aga pigem sümboolne - ja paraku mitte väärindavas mõttes. Tundub, et see peegeldab hästi ka meie praegust ühiskondlikku olukorda ja soomeugrilist taju. Rasket riigitööd tegev poliitik saab huvituda esmajärjekorras ikkagi vaid kindlast kasust. Soomeugriluse kaal rahvusvahelises poliitikas pole eriti võrreldav näiteks turgi rahvaste ja riikide seas toimuvaga, mida suunab ennekõike Türgi. Soomeugrilus pole laiatarbekaup, mida annaks meedias igapäevaselt müüa, seega pole ta paraku ka väga nähtav. Hea siiski, et 2011. aastast tähistatakse meil oktoobrikuu kolmandal laupäeval riikliku tähtpäevana hõimupäeva. Hõimupäeva idee ulatub tagasi 1931. aastasse. Vastav otsus tehti Helsingis toimunud soomeugri IV kultuurikongressil. 1930. aastatel sai hõimupäeva tähistamine Eestis heaks tavaks, kuni maailmasõda traditsiooni katkestas.

\section{Sõda ja uks itta}

Nõukogude võim likvideeris endised riiklikud ja ühiskondlikud struktuurid ning formaliseeris nõukogulikkuse sildi all rahvuslikud tegevused. Samas avanes võimalus otsesidemeteks idapoolsete hõimurahvastega, nende välitöiseks uurimiseks ja vastavateks teaduskontaktideks Venemaa teadlastega. Kuid veel enne nõukogude võimu tsementeerumist kasutasid Eesti rahvusteadlased ära sõja ja rinde itta liikumisega tekkinud võimalusi lähialade (Ingerimaa) 
hõimurahvaste uurimiseks. 1942. ja 1943. aasta suvel tehtud ekspeditsioonid ja sealt kogutud materjalid ja muljed said olulisteks allikateks sõja lõpul läände põgenenud eesti humanitaaridele, nagu Eerik Laid, Julius Mägiste, Felix Oinas, Gustav Ränk, Ilmar Talve. 1942. aasta ekspeditsioonil osales ka Paul Ariste, kes sõja puhkedes oli Tartus saanud tegelda komi rahvusest nõukogude sõjavangidelt komi keelenäidete ja folkloori kogumisega.

Diasporaas, pagulasringkondades muutus eestluse hoidmine ja taastootmine kohe pärast sõda keskseks teemaks. Oma osa moodustas selles ka soomeugri komponent, olles ennemini rahvusmüüdi kui teaduslike edasiarengute teenistuses. Rahvusteadlaste programmilistes kirjutistes kohtab soome-ugri hõimluse ja hõimurahvaste teadvustamist vahelduva eduga. Just pagulaskonnast on pärit XX sajandi teise poole eesti rahvuslusega seotud põhitekstid. Eelmises lõigus nimetatud meeste kirjutistes võitleb müüt fakti, tõelisus nägemuslikkusega. Soome-ugri teema on paiguti tähelepanu all rahvusmüüdi ehitamisel Harri Moora, Oskar Looritsa (vrd 1951) jt kirjatöödes, aga ka selle kriitikas (nt Laid 1997 [1995]). Siiski leidis aset ka hõimurahvaste teaduslik tutvustamine (näiteks Valev Uibopuu, Felix Oinas jt) ning vastav uurimistegevus. Neis kirjatöödes on antud vajalik ja üsna objektiivne ülevaade meie hõimlaste keelest, kultuurist ja toonasest olukorrast.

Loomulikult polnud sel ajal Nõukogude Eestis võimalik arutleda tegeliku rahvusideoloogia üle. Stalinistlikul perioodil pidid ka rahvusteadused otsima ja leidma seoseid vene kultuuriga, internatsionalistlik ideoloogia välistas mis tahes natsiooni idee. Alates 1930. aastate teisest poolest oli Venemaal alanud totaalne venestamispoliitika, mille tulemusena toimus kahe järgneva põlvkonna jooksul väikerahvaste ulatuslik keeleline assimileerumine. Eesti tavamõtlemises seostus ida punaterrori, küüditamise, vabaduse kaotusega, silma paistis Venemaa eestlaste osakaal juhtivatel ametikohtadel. Ida polnud huvipakkuv, vaid hirmutav.

Teaduslik areng hõimurahvaste uurimisel algas pärast sõda, kui olud stabiliseerusid. Tartu Riiklikus Ülikoolis (TRÜ) algasid juba 1940. aastate lõpust iga-aastased ekspeditsioonid läänemeresoome rahvaste juurde. Uurimistöös osalesid pea kõik rahvusteadustega tegelevad teadusasutused. Need ei olnud ühepoolsed suundumused ja sidemed: nõukogude ajal kujunes suuremal või vähemal määral välja mitmepoolne koostöö Venemaa fennougristide ja vastavate uurimisasutustega. Olulisteks märksõnadeks said välitööd ja uurimistegevus kohtadel, mida sellises mahus kunagi varem toimunud polnud. XX sajandi teine pool on niisiis vaieldamatult kõige viljakam periood Eesti fennougristikas, seda tänu vahetut uurimistegevust soodustavatele taustaoludele ning tõigale, et Venemaa eri piirkondades oli võimalik töötada veel elujõuliste omakeelsete ja ka -meelsete kogukondadega.

Ennekõike mainigem TRÜ-d ja Paul Ariste isikut. Ariste uurimistegevus fennougristina sai alguse juba enne sõda, mil tal õnnestus tööd teha Ingerimaa keelejuhtidega, 1942. aastal aga osaleda juba ise välitöödel Saksa tagalasse jäänud vadja külades. Ariste isiklik välitööpõhine vadja-huvi vältas kuni 1980. aastateni. Tema juhendamisel ja temaga koos kasvas Tartus üles mitu põlvkonda soome-ugri keelte uurijaid. Ülioluline on Ariste tegevus soome-ugri päritolu aspirantide juhendajana. See on ilmekas näide, kuidas teadustegevus ning hõimutöö saavad käia ühte jalga. Oma ida poolt pärit juhendatavatele 
andis ta edasi rahvusliku iseolemise vaimsuse ning see seeme ei kukkunud viljatule pinnale.

Nii nagu inimsuhtluses, polnud Ariste mingi kuivik ka hõimurahvaste uurimisel. Vadja välitöödel ei kogunud ta mitte lihtsalt keele- ja folkloorinäiteid, vaid sisendas rahvustunnet ning esitas oma visioone (ehk ka fantaseeris) talle emotsionaalselt olulistel hõimuteemadel. Näiteks jookseb tema päevikumärkmetest läbi ürg-vadja mõiste - tunnetus, mida ta oma parimate keelejuhtide maailmapildis uskus tabavat (vt ka Arukask 2003). See mõtteline, ennekõike rahvausus kajastunud nähtus ulatus kaugemale XX sajandil üha intensiivistunud venestusest ja oli seeläbi Ariste (ning ta mõttelise eesti lugeja) jaoks enam „oma” kui kaasajal valitsenud nõukogude tegelikkus. Kahtlemata suutis Ariste pikkade aastate jooksul sisendada oma vadja vestluskaaslastele arusaama, et nad pole mingid imelikku keelt kõnelevad poolvenelased, vaid oma keele ja kultuuriga iseseisev rahvas. Ta oli paljudele teejuhiks soome-ugri maailma, mis omakorda oli midagi enamat kui vaid XIX sajandil konstrueeritud teadmine keelesugulusest.

Ariste jälg on suur ja ilmselt on kellelgi teisel võimatu sellist jälge jätta, seda nii tema erakordsete isikuomaduste kui ka 1990. aastatest muutuma hakanud olude tõttu. Sugugi mitte kõik tema kaasaegsed polnud sama võimekad hõimumõtte arendamises teadustööga paralleelselt või põimuvalt. Teaduse tegemine oma hermeetilisuses võib kanduda kabinetist välja põllule, inimeste, kogukondade, kultuuride hulka, keda justkui uuritakse. Keeleteaduses või etnograafias võib seesama soomeugrilane, inimene, osutuda tülikaks vahelüliks, keda oma uurimisülesande peal väljas oleval teadlasel on vaja vaid senikaua, kuni vajalik materjal käes. Sellised mõtted siginevad mõnikord näiteks ENSV Riikliku Etnograafiamuuseumi (nüüd jälle Eesti Rahva Muuseumi / ERM) pikaajalise direktori Aleksei Petersoni välitööpäevikuid lugedes, ning Petersoni näide pole siin kaugeltki ainulaadne.

Samal ajal oli Peterson muuseumijuht, kelle eesmärgile pühendumus viis silmatorkava soome-ugri etnograafiakollektsiooni loomiseni Eestis. Teadusliku uurimis- ja päästmistöö tulemusena on meie käsutuses aines uuteks soomeugrilisteks mõtestamisteks ja ümbermõtestamisteks. Siiski toimis Peterson ekspeditsioonijuhina vepsa või udmurdi külades sageli kui taluperemees oma kartulimaal, kus armastusele jäi ruumi ainult pärast tööd, mis aga kunagi otsa saada ei ähvardanud.

Nõukogudeaegsete eesti rahvusteaduste (ennekõike keeleteaduse, folkloristika, etnograafia) ainus tõsisemalt arvestatav välispartner läänes oli Soome teadusruum ning sealsed kolleegid, kellel olude paranemisega Hruštšovi sula aegadest õnnestus üha tihedamini ka Eestit külastada. Teaduses oli „Soome sild” ehitatud loomulikult juba sada aastat varem ning tugevnenud ennesõjaaegses eestikeelses ülikoolis. See ühendus oli samaaegselt ka väga soomeugrilik ning oma ajas tõsiselt kaalukas. On märkimisväärne (kuigi mitte tingimata ihaldusväärne), kui palju rahvusvahelist teadusinfot tuleb läbi soomeugrilise filtri. Rõhutan seda, sest näiteks soome folkloristikas kestis selline eritähelepanu soome-ugri temaatikale kuni XXI sajandi alguseni. Selliste maailma folkloristika gigantide nagu Lauri Honko või Anna-Leena Siikala jaoks olid soome-ugri temaatika ja soome-ugri päritolu teadlased alati huvitavad ja soositud, väga erilised muu maailma teaduskogukonna seas. 
Tänaseks on olukord ka Soomes muutunud. Siiski toob iga viie aasta tagant soome-ugri uurimisteemadega seotud uurijaid kokku 1960. aastal alguse saanud eri maades toimuv rahvusvaheline fennougristika kongress. Seni on toimunud 12 kongressi ning näib, et ürituse kese on nihkumas üha rohkem keeleteaduse poole ja laiema hõimuhuvi asemel domineerib hermeetiline erialateaduslikkus. Silmapaistev on ka 1984. aastal alguse saanud rahvusvaheliste iga-aastaste soome-ugri üliõpilaskonverentside (International Finno-Ugric Students' Conference / IFUSCO) traditsioon, mis peab aga üha enam rinda pistma nii korralduslike kui ka poliitiliste probleemidega.

Nõukogude ajal olid ekspeditsioonitegevusse soomeugrilaste juurde haaratud folkloristid, etnograafid, keeleteadlased, füüsilised antropoloogid ülikoolidest, Keele ja Kirjanduse Instituudist, etnograafiamuuseumist. Märkimisväärne on Ingrid Rüütli 1960. aastatel alanud teadustegevus soome-ugri etnomusikoloogia vallas: tal õnnestus luua eri rahvaste ja maade musikoloogidest koosnev võrgustik ning ekspeditsioonid ja teadusüritused olid ühtlasi ka hõimuüritused. Oluline märk hõimuidee levikust teadusringidest ühiskonda oli 1974. aastal populaarteaduslikus sarjas „Mosaiik” ilmunud Ago Künnapi, Paula Palmeose ja Tõnu Seilenthali kirjutatud raamat „Põhja ja itta. Lehekülgi meie sugulaskeelte uurimisloost". Lugeva eestlase jaoks oli see kahtlemata oluline infoallikas ja mäluvärskendaja meie hõimurahvastest ja hõimukuuluvusest.

Tähtsana tuleb ära märkida ka toonases Eesti Riiklikus Kunstiinstituudis 1978. aastal alguse saanud välitööde traditsioon, mille ellukutsuja ja pikaajaline juht oli Kaljo Põllu (seda samuti Paul Ariste õhutusel). Nagu Põllu on maininud, „oli veel algusaastail kavatsus teha ekspeditsioonidest osavõtnute eriline kunstirühmitus ja arendada välja omanäoline, soome-ugri rahvakultuurile toetuv loominguline lähenemisviis" (Põllu 1997). See programmiline taotlus ei saanud ekspeditsioonidel osalenute erialastest huvidest tulenevalt siiski teoks. Kunstnike ja kunstitudengite loome- ja uurimistegevus on oluliselt rikastanud meie soomeugrilist aistingut. See on olnud sellealases müüdiloomes meie identiteedi lisakanaliks. See on andnud ehk ka eesti kultuuris domineeriva soome-ugri visuaali - kaljopõllulikult hämaratoonilise ja madalalaelise „kodalaste kuvandi”, mis mõnes mõttes üheülbastab soome-ugri tegelikkust, on aga samas hõimuteema iseloomuliku peegelduse näide meie rahvusteadvuses. Lisagem siia veel Veljo Tormise soome-ugri rahvamuusikal põhinevad teosed ning eesti kultuuri soome-ugri maastik ongi valmis. Tegelikkuses ei ela suurem osa soomeugrilasi madala taeva aluses mustvalges koopas šamaanitrummi põristades, see on meie endi kujutelm siin Läänemere-äärses Eestis ning vististi peegeldubki sellises soome-ugri kuvandis eestlaste endi minapilt. Kes on käinud Mordva- või Udmurdimaa avarustel, saab aru, millest jutt. Ka meist vähem kui tuhat kilomeetrit ida pool elavate vepslaste asuala reljeef on sageli vaheldusrikkam ja taevas seetõttu kõrgemal.

Soome-ugri hõimlus kujunes nõukogude perioodi viimasteks kümnenditeks osa eesti intellektuaalide jaoks ka vastukultuuri allikaks, sarnaselt eheda eesti rahvakultuuriga, mida võidi eraldi hoida nõukogulikust rahvakultuurist ja rahvusromantilisest šabloonsusest. Ehe soomeugrilik rahvalaul ja -muusika (mida Tartus alates 1970. aastatest viljeles ansambel Hellero) oli vastukultuur oma leebetes, kuid veenvates vormides. Sedasama võib tajuda ka Lennart 
Meri töödes, eriti soome-ugri rahvastest tehtud filmides: „Veelinnurahvas” (1970) ja „Linnutee tuuled” (1977) on püüd visuaalseid vahendeid kasutades pakkuda keelesuguluse teooriale kultuurilist kinnitust. Etnograafilistes filmides põimuvad teaduslikkus ja sugulusmüüt, mida põlistab sugestiivselt autoriteksti lugenud Mikk Mikiveri häälekärin. Kahtlemata oli sellel mõju.

\section{Uuel aastatuhandel}

Elame XXI sajandil, ajalugu ei ole otsa saanud, raudne eesriie on nihkunud lihtsalt natuke ida poole, olles jällegi tihendanud füüsilist piiri meie ja meie idapoolsete hõimurahvaste vahel. Internet on küll näiliselt kõikjale imbuv sidekanal, mis riigipiire ei tunne, kuid ta ei asenda kuigivõrd inimsuhtlust, veel vähem rahvaste tegelikku tundmist ja tundmaõppimist. Tegus on veel uurijate põlvkond, kelle tegevus sai alguse nõukogude perioodil, kui pääs itta oli lihtsam - Enn Ernits, Aado Lintrop, Triinu Ojamaa, Heinike Heinsoo jt. Täies jõus on 1990. aastatel alustanud välitööpõhiste uurijate põlvkond (Art Leete, Laur Vallikivi, Liivo Niglas, siinkirjutaja jt). Uuel aastatuhandel pole uurijate pealekasv olnud enam nii hoogne, fennougristika Tartu Ülikoolis ei evi Ariste-aegset sära. Nagu teaduses tavaks saanud, ripub uurimistegevus projektirahade, mitte ulatuslike visioonide ja tööplaanide küljes. Fennougristikal sellist suurt plaani ei paista olevat, see ei ole enam distsipliinideülene idee, vaid peab võistlema uute teeadussuundadega, omamata enam kaugeltki samasugust löögijõudu. Näib, et eesti rahvusteadused on vaevas eesti kultuuri ja keele olemasolu vajalikkuse tõestamisega. Soomeugrilus omakultuurilisuse ühe argumendina võib siin olla justkui toeks, aga kas ka koormaks?

Teadusliku kitsuse kõrval hoitakse soomeugrilust üleval nii hobitegevuses kui ka riiklikult toetatud institutsioonide kaudu. 1991. aastal taastatud Fenno-Ugria Asutus on ennekõike soome-ugri kultuure ja kultuurikontakte haldav organisatsioon. Iga-aastane hõimunädal oktoobris püüab olla laiemalt nähtav, minnes aga korda ennekõike aastatega väljakujunenud sihtgrupile. 2012. aastast alustas ilmumist aastaraamatu formaadis jätkväljaanne „Soome-ugri sõlmed”, mis on huvilistele oluliseks allikaks aasta jooksul sündinust. Asutuse kodulehel (www.fennougria.ee) hoitakse Eesti lugejat kursis soome-ugri maailma sündmustega.

Rahvusvahelise ja rahvuspoliitilise soome-ugri koostöö areeniks on soomeugri rahvaste maailmakongressid. See traditsioon sai alguse 1992. aastal ning peegeldas uute tuulte saabumist Venemaal ja Ida-Euroopas. Seni seitsmel korral toimunud kongressi peetakse iga nelja aasta tagant kordamööda Venemaal, Ungaris, Soomes ja Eestis. Kongressi töö keskendub ootuspäraselt rahvaste elu „pehmele” poolele, kuid tänasel päeval ja taas raskenenud ida-lääne suhtluses ei taga ka see enam probleemideta ettevalmistus- ja korraldustööd. Peamiselt Tartu Ülikooli fennougristikatudengitest koosnev rühmitus FennoUgria Noored kannab muutuvas ajas edasi uue põlvkonna hõimuideed, arendab ülivajalikke sidemeid hõimurahvaste noorsooga Venemaal ja mujal ning esindab Eestit IFUSCO-del.

Eesti riigi toel antakse välja erinevaid preemiaid ja uurimisgrante, toetatakse hõimurahvaste kultuurilisi ettevõtmisi aastast 1999 eksisteeriva hõimu- 
rahvaste programmi kaudu. Programmi abil on Eesti ülikoolidesse õppima pääsenud hulgaliselt Venemaa soomeugrilastest tudengeid. Praeguse, programmi neljanda etapi sissejuhatus ütleb: „Käesoleva programmi lähtekohaks on eestlaste kuulumine soomeugrilaste hulka. Eesti kultuur baseerub lisaks euroopalikule algele ka vanal soomeugrilisel rahvakultuuril, millel on palju ühist teiste uurali rahvaste kultuuridega. Nii moodustavad hõimurahvad meile hädavajaliku kultuurilise tagala. Paraku on nende säilimine ja arenemine raske - mõnel juhul isegi võimatu - ilma välise abita. Teades ja tunnustades sugulasrahvaste kultuuride väärtust nii eestlaste kui kogu inimkonna jaoks, on Eesti riigi ja ühiskonna kohus seda abi pakkuda." (Hõimurahvaste programm IV) See kõlab kohaselt riigile, kes suudab oma ainelises väiksuses olla suur vaimult ja teolt. Hetkel pole aga täit kindlust, kas programm tulevikus sellisel kujul jätkub. Nagu ikka võib valdkondadevaheline koostöö osutuda eri ministeeriumidele ületamatult raskeks. Paraku on soome-ugri maailm mitmekesisem ja laiem mõne ministeeriumi valdkonnakesksusest.

1990. aastatel ühiskonnas puhuma hakanud värsked tuuled on XXI sajandil vaikselt Euroopa Liidu ventilatsioonitorudesse suubunud. Õhukesel riigil on tarvis üksnes hädavajalikku, mitte niivõrd unistusi ega haaret. Eesti Vabariigi põhiseaduses hõimuideest või soome-ugri osast keeles ja kultuuris juttu pole. XX sajandi eesti kultuuri ja Eesti riigi ühe suurema visionääri Lennart Meri soomeugrilik mõtegi pöördus presidendiks saades otse loomulikult läände. Nõukogude perioodi idaavaruste hõimuunistuslikkusest sai ta kõnedes sajandi lõpuks Eesti läänekõlblikkuse tõestusmaterjal, millele on muiates tähelepanu juhtinud ka Jaan Kaplinski (2004a [1995]).

Soome-ugri müüt elab edasi huviliste hobi- ja loometegevuses. Kõva tööd Venemaa soome-ugri rahvaste kirjanduse tõlkimisel ja tutvustamisel on aastakümnete jooksul teinud Arvo Valton. Märkimisväärseid avanguid on teinud Henn Haabsaar, Hasso Krull, ka Valdur Mikita. See rivi pole kuigi pikk. Võib muidugi lohutada, et näiteks Ungariga võrreldes on meil leebe rahulolu oma soomeugrilikkusega kogu aeg alles ja justkui valdav: keegi ei sea meie „ugrimugri" päritolu siin ju kahtluse alla.

Teaduse ja soome-ugri müüdi viimaseid jõulisi põimumisi (kui seda nii sõnastada võib) oli ehk soome keeleteadlase Kalevi Wiigi mõtlemist virgutav uutmoodi nägemus soome-ugri rahvaste pärinemisloost ja Euroopa ürgsest minevikust, mis traditsioonilise fennougristika talasid vahepeal kõigutama kippus. Eestis oli ja on tema vaate suurimaid toetajaid Tartu Ülikooli emeriitprofessor Ago Künnap. Kuigi keeleteadusest on see lugu nüüdseks „välja kirjutatud”, oli huvi Wiigi raamatu „Eurooplaste juured” (Soomes ilmus „Eurooppalaisten juuret” 2002, eesti keeles 2005) vastu tavalugejate seas XXI sajandi algul Soomes ja Eestis suur. Samas ei ole soome-ugri narratiiv teaduspoliitiliselt mingil juhul võimeline kõigutama gigantset indoeurooplust, kaalukategooriad on selleks liiga erinevad. Vist peabki soomeugrilus nii teadusliku uurimisobjekti kui ka ühiskondliku fenomenina mahutuma metafoori „väike on ilus" alla. Ilu on muidugi alati vaataja silmades. Teadusliku huvi jätku meie (muuhulgas ka) soome-ugri päritolu vastu kinnitab viimastel aastatel hoogustunud interdistsiplinaarne tegevus, mille nähtavaks väljenduseks on 2017. aastal Tartu Ülikoolis loodud arheoloogia, geneetika ja lingvistika sidusuuringute kolleegium. Nagu ütles selle üks loojatest, Tartu Ülikooli arheoloo- 
giaprofessor Valter Lang: „[---] uuriti Eesti rahva ja naaberrahvaste etnilist ajalugu meil viimati sel moel 60 aastat tagasi. [---] Kolleegium ongi mõeldud ühendama erinevaid teadusi etnogeneesi uurimisel, kusjuures nende teaduste nimekiri ei saa kindlasti piirduma üksnes seni kaasatutega." (Eestlaste etniline ajalugu...) Ootuspäraselt tegeleb interdistsiplinaarne uurimistöö suuresti ka eriliigilise soome-ugri allikmaterjaliga.

Soomeugriluse viimaseid suuri edulugusid Eestis on seotud 2016. aastal avatud uue Eesti Rahva Muuseumi hoonega. Hästi koostatud ja kujundatud soome-ugri püsinäitus „Uurali kaja”, mille sisupoole lõi TÜ ja ERM-i soomeugri rahvaste uurimisega tegelevatest teadlastest koosnev töörühm, on juba võitnud mitmeid auhindu (nt 2017. aastal väljaantud Euroopa disainiauhindade peapreemia) ning saanud arvukatelt külastajatelt positiivset tagasisidet. Alates ERM-i uue maja avamisest oktoobris 2016 oli selle näitusi 2017. aasta lõpuks külastanud üle 350000 inimese. Loodetavasti külvab „Uurali kaja” eesti publikusse rohkem huvi meie hõimlaste vastu. Näitus on pühendatud just väikestele hõimurahvastele, sealt on välja jäänud soomlased ja ungarlased (loomulikult ka eestlased, kelle jaoks on ERM-is eraldi püsinäitus).

\section{Kokkuvõtteks ja kokkumõtteks}

Millega mõõta soome-ugri komponendi olulisust eesti kultuuris ja identiteedis, selle suurust või väiksust? Eesti endapildis on kaalukausil kaks nägemust: üks, mille järgi me oleme väiksed ja peame pugema kellegi hõlma alla, ning teine, mille järgi me oleme piisavalt suured, vähemalt vaimus (nagu seda soovis Jakob Hurt), et olla meie ise ja toetada endast väiksemaid. Arukalt võttes ei peaks need kaks perspektiivi vastanduma, kuid tegelikkuses kipub üks teist alati varjutama, seda nii päevapoliitilises debatis kui ka inimeste argiteadvuses.

Esimeses vaates märgistab soome-ugri ja hõimurahvaste temaatikat igavese hääbumise ja rahvaste üksteisest kaugenemise meem - ja kõige sellega ei peaks meil justkui pistmist olema. Selle mõtteviisi objektiivsed juured on faktis, et soome-ugri rahvad pole kunagi olnud suured ja „edukad”, piisavalt silmapaistvad, et väärida tähelepanu või lugupidamist. Mis on selle mõtteviisi sõnum eestlastele, eesti identiteedile? Et ei tasu sarnaneda, et soomeugrilusel pole kasulikku perspektiivi. Sõbrad olgu ennekõike „suuremad poisid”, mitte omaksed. Suhted hõimlastega olgu ettevaatlikud ja hermeetilised - nii teaduslikult kui ka meeleliselt. Kultuurilised erinevused on aluseks võõristusele, mitte huvile. Kõik idapoolne kuulugu ja jäägu meist eemale, Venemaa euroasianismi podisevasse katlasse. Nii mõeldes asume Maslow' püramiidi alumistel korrustel, kuid eks ole ju seegi tubli resultaat.

XIX sajandi ärkamisajal alanud hõimuhuvi oli oma olemuselt emotsionaalne ja dialoogi sooviv. Kasutades Martin Ehala määratlust, oli see identiteedi „kuum” etapp, „mille puhul on etnoseliikmete seas sotsiaalseks normiks tugev emotsionaalne seotus rühmaga ja kõrge valmisolek kollektiivseks tegutsemiseks" (Ehala 2009: 20). Hetkel on see ilmselt möödanik. Soomeugrilus oli siis (ehk ka sõjaeelses vabariigis ning vahest 1990. aastate alguseski) innustav rahvustöö osis. Hõimuliikumise soojus ja emotsionaalne huvi rahvaste vastu 
on praegu paigutine, vaid osadele kordaminev. Ehala sõnul oleme nüüd pigem „külm etnos”, mille „liikmed on valmis panustama kollektiivsete eesmärkide saavutamiseks ratsionaalseil kaalutlustel - kui see on neile kasulik või vajalik süsteemipoolsete sanktsioonide vältimiseks" (Ehala 2009: 26). Soomeugrilus (ka eestlaseks olek, keel ja kultuur) pole selle järgi hetkel emotsioon, vaid miski, mille üle ratsionaalselt kalkuleeritakse.

Meie idapoolsetel hõimurahvastel on kõigele vaatamata vaja meie tuge, kas või emotsionaalset tuge. Selles saab väljenduda meie suurus neile, aga ka iseendale. Soomeugriluse osa eesti identiteedis on Jaak Prozes sõnastanud järgmiselt: „Me vajame soomeugrilist identiteeti, koos oleme tugevamad, suuremad ja võime mõelda suuremalt. Koos suudame ehk ka paremini kaitsta oma kultuurilist iseolemist, mis on vajalik, et jääda rahvusena püsima. Mida nõrgem on meie rahvuslik identiteet, seda nõrgemad ja altimad oleme võõrmõjudele, kes kas tahtlikult või tahtmatult suruvad peale mõttelaade, mis võivad meile ohtlikud olla. Pean silmas mõttelaadi, mille kohaselt oleks meile parem minna üle ingliskeelsele kõrgharidusele ja teadusele, et tuleks vähendada emakeeletundide arvu võõrkeelte arvelt, lapsed võiksid juba lasteaias süvendatult võõrkeelt õppida, enne kui emakeel selge jne. Need on ohumärgid. Olgem siis valvsad!" (Prozes 2017)

Soomeugrilus on kõigele vaatamata meie vaimse iseolemise, rahvusluse sissejuurdunud osa. Milline on rahvuslus uuel aastatuhandel - kas kiivas isoleeritus või kestev eneseküllane, sealhulgas soomeugrilik müüdiloome? Kuivõrd on meil selleks sisemist ressurssi, eriti siis, kui eurotoetused igas mõttes lõppema peaks? Kas soomeugriluses on eesti identiteedi kese või on see meie võõristust tekitav alter ego? Kui sisuliseks debatiks jaksu ja asjatundlikkust napib, võiks vastuse anda sellekohane üldrahvalik küsitlus, loomulikult korralikult ette valmistatud ja fokusseeritud.

Artikli valmimist on toetanud Eesti Vabariigi Haridus- ja Teadusministeerium (projekt IUT2-43 „Traditsioon, loovus ja ühiskond: vähemused ja alternativvsed diskursused" ning Hõimurahvaste programm).

\section{Kirjandus}

Adamson, Andres 2017. Soome ja Eesti ajaloost veidi teistsuguse vaatenurga alt. - Postimees AK: arvamus, kultuur, 2. XII. https://arvamus.postimees. ee/4324393/andres-adamson-soome-ja-eesti-ajaloost-veidi-teistsuguse-vaatenurga-alt (29. XII 2017).

Arukask, Madis 2003. Paul Ariste ürgvadjaluse kontseptsioon ja Oudekki Figurova. - Mäetagused, nr 21, lk 222-230. www.folklore.ee/tagused/nr21/arukask.pdf (29. XII 2017).

Eestlaste etniline ajalugu taas mitme eriala ühise luubi all. - Tartu Ülikooli kodulehekülg. https://www.ut.ee/et/uudised/eestlaste-etniline-ajalugu-taas-mitmeeriala-uhise-luubi-all (29. XII 2017).

Ehala, Martin 2009. Etnolingvistiline jätkusuutlikkus ja seda mõjutavad tegurid. - Teadusmõte Eestis (V). Humanitaarteadused. Toim Jaan Ross, Arvo 
Krikmann. Tallinn: Eesti Teaduste Akadeemia, lk 19-34. http://lepo.it.da. ut.ee/ ehalam/pdf/etnosust2009.pdf (29. XII 2017).

E is en, Matthias Johann 2008 [1922]. Eestlaste sugu. Koost Urmas Sutrop. Tallinn: Eesti Keele Sihtasutus, Tartu Ülikool.

Hõimurahvaste programm IV (2015-2019). - Fenno-Ugria kodulehekülg. https:// fennougria.ee/toetused/hoimurahvaste-programm/hoimurahvaste-programm-iv (29. XII 2017).

Kaplinski, Jaan 2004a [1995]. President teeb rahvale ajalugu. - J. Kaplinski, Kõik on ime. (Eesti mõttelugu 55.) Koost Toomas Salumets. Tartu: Ilmamaa, lk $43-45$.

Kaplinski, Jaan 2004b [1998]. Soome-ugri pärandus. - J. Kaplinski, Kõik on ime. (Eesti mõttelugu 55.) Koost Toomas Salumets. Tartu: Ilmamaa, lk 192-193.

Kr u ll, Hasso 2014 [2010]. Soomeugri müüt. - H. Krull, Pesa. Tekstid 2000-2012. Tallinn: Eesti Keele Sihtasutus, lk 239-246.

Laid, Eerik 1997 [1955]. „Ajalooline” Loorits. - E. Laid, Paopaigad. (Eesti mõttelugu 13.) Koost Pekka Erelt, Hando Runnel. Tartu: Ilmamaa, lk 337-339.

L o o rits, Oskar 1951. Eestluse elujõud. (Iseseisvuslaste kirjavara 5.) Tõrvik.

Peter s o n, Kristian Jaak 2001. Etwas über die Ehsten, ihre Abstammung, u.s.w. - IAAK. Kristian Jaak Peterson 200. Toim Kristiina Ross. Tallinn: Eesti Keele Sihtasutus, Underi ja Tuglase Kirjanduskeskus, lk 188-207.

Prants, Hindrik 2008 [1919]. Soome sild. Eesti-Soome ühtsus aastatuhandete jooksul. - Loomingu Raamatukogu, nr 5. Tallinn: SA Kultuurileht.

Pr o z e s, Jaak 2012. Hõimuliikumine ja Fenno-Ugria Asutus. - Soome-ugri sõlmed 2010-2011. Toim Üve Maloverjan. Fenno-Ugria, lk 104-114.

Prozes, Jaak 2017. Eesti-Soome suhete madalseisus sündinud identiteedileping. - Sirp 1. XII. http://www.sirp.ee/s1-artiklid/c9-sotsiaalia/eesti-soome-suhetemadalseisus-sundinud-identiteedileping (29. XII 2017).

Põllu, Kaljo 1997. Eesti Kunstiakadeemia soome-ugri uurimisreisid läbi aastate. - Hõimusidemed. Fenno-Ugria 70. aastapäeva album. Tallinn, trükis ilmumata. http://www.suri.ee/hs/pollu.html (29. XII 2017).

\section{Finno-Ugric kinship in the Estonian national image: A shared emotion or a fuzzy question?}

Keywords: Finno-Ugric kinship movement, identity, Finno-Ugric peoples, research history

The essay is a contemplation on the role and meaning of Finno-Ugric kinship as part of modern Estonian identity. The focus is on the relations between Estonians (in particular, scholars and other intellectuals) and Finno-Ugric peoples since the early $19^{\text {th }}$ century, as well as on the reflections of the kinship concept in the Estonian society in different periods. The idea of Finno-Ugric kinship actually germinated in the theory of language affinity, which emerged and developed in the $19^{\text {th }}$ century. However, a scientifically hermetic theory can hardly function as a single component of either a movement or a people's group identity. In different times the popularity and influence of the Finno-Ugric kinship idea has differed. Differences can also be observed in the attitude towards the Eastern and Western (Finnish, 
Hungarian) kindred peoples due to the formers' long experience of living under Russian rule and in the Russian cultural space.

In the $19^{\text {th }}$ century, during the period of National Awakening, Estonians found the idea of Finno-Ugric kinship topical and hot enough. At that time it mainly meant a relatively one-sided admiration of the cultural achievements of the Finnish people, who, like a bigger brother, was looked up to as an ideal example of getting things done under the rule of Tsarist Russia. In the pre-war Estonian Republic, kinship activities enjoyed a relatively high national prestige, but real contacts with the Finno-Ugric peoples of Russia were limited for political reasons. Real scientific research and contacts became possible only after the war was over, which period was the heyday of Finno-Ugric research in Estonia. Another upsurge of Finno-Ugric interest arrived at the early 1990s, when the collapse of the Soviet Union entailed a great social upheaval in Estonia. The $21^{\text {st }}$ century has brought about a gradual withdrawal of emotions from identity issues. A pragmatic attitude has come to prevail not only where Finno-Ugric matters are concerned, but also in questions of the Estonian language and culture as such.

Madis Arukask (b. 1969), PhD, University of Tartu, Faculty of Arts and Humanities, Associate Professor / Senior Researcher, madis.arukask@ut.ee 